\title{
Paul Tillich em diálogo com o Budismo Amidista Japonês: novas questões
}

\author{
Elton Vinicius Sadao Tada*
}

\begin{abstract}
RESUMO
O presente artigo tem como intenção colocar em diálogo a teologia de Paul Tillich com o Budismo Amidista japonês. O próprio Paul Tillich iniciou esse diálogo em sua visita ao Japão em 1960, mas deixou várias questões a serem respondidas. A partir desse passo inicial tentaremos propor um diálogo pormenorizado, tendo como centro a preocupação sobre a questão da salvação no Budismo Amidista japonês e sua validade em relação ao pensamento tillichiano.
\end{abstract}

Palavras-chave:Paul Tillich; Budismo Amidista; Budismo Japonês

\section{Paul Tillich in dialogue with Japanese amidst Buddhism}

\begin{abstract}
The present paper intends to put in dialogue the theology of Paul Tillich and the Japanese Amidst Buddhism. Paul Tillich himself started this dialogue in his visit to japan on 1960, but he left a lot of questions to be answered. Parting from this initial step we will try to propose a detailed dialogue, having as center the preoccupation about the salvation task on Japanese Amidst Buddhism and its validity in relation with Paul Tillich's thought.
\end{abstract}

Key-words: Paul Tillich; Amidst Buddhism; Japanese Buddhism

\section{Introdução}

O pensamento de Paul Tillich tem sido estudado há várias décadas. Quando o autor ainda era vivo já despertava o interesse de estudiosos ao redor do mundo que buscavam entende-lo e criticá-lo dentro do

\footnotetext{
* Bacharel em Teologia. Doutor em Ciências da Religião - UMESP. Professor da Famma - Faculdade Metropolitana de Maringá. E-mail: eltontada@yahoo.com.br.

Currículo Lattes: http://lattes.cnpq.br/3346620537310887.
} 
grande espectro de assuntos abordados em sua obra. No Brasil, em especial, o trabalho de Tillich é mais reconhecido em seu viés teológico, sobretudo a partir do domínio de sua teologia da cultura. Entretanto, assim como os assuntos tratados pelo autor são variados, suas abordagens também o são. A primeira formação de Paul Tillich foi a filosofia, contando com uma jornada de constantes mudanças por universidades alemãs, como era comum no início do século passado. Depois do término de sua formação em filosofia é que o autor pôde habilitar-se em teologia, assumindo em seguida o cargo de ministro na igreja luterana da Alemanha. Com tal papel, Paul Tillich serviu como capelão militar na primeira guerra mundial, sendo que sua primeira grande mudança de pensamento se deu justamente lá, nos campos de batalha. Tillich vivenciou a experiência da morte e da bestialidade humana de maneira muito próxima e cotidiana, de modo que não pôde permanecer alheio a isso, desenvolvendo em si um questionamento pelos sentidos primeiros e pelas formas de discurso metafísico muito próximo ao que se transformaria posteriormente na corrente de pensamento existencialista. $\mathrm{O}$ autor esteve pertode autores que acabaram se tornando figuras importantes do século XX, como Theodor Adorno, Marx Horkheimer, Erich Fromm, Mircea Eliade e Carl Rogers.

Com o surgimento do regime nazista, Paul Tillich viu seu próprio país tornar-se um local inóspito, e mudou-se para os Estados Unidos da América a convite de Reinhold Niebuhr, passando a lecionar no Union Theological Seminary. Foi no período estadunidense que Paul Tillich pôde se aproximar ainda que levemente do budismo. Não se sabe exatamente como se deu essa aproximação, mas são conhecidos alguns interlocutores que o autor teve e universidades estadunidenses, entre eles Richard De Martino e Daisetsu Teitaro Suzuki (1870-1966). Em 1960, quando Paul Tillich vai ao Japão, seu tempo é dividido entre as escolas da Terra Pura e as escolas Zen budistas. A maior parte do tempo é dedicada ao diálogo com o Zen Budismo. Entretanto, uma semana da estadia é dedicada a conhecer a cidade de Kyoto, onde se dá o diálogo com os pensadores do budismo amidista.

Para Paul Tillich, que construiu seu pensamento no contexto das fronteiras, vivenciar algo tão diferente como a cultura japonesa foi um deleite que o impactou fortuitamente. Há a indicação, inclusive, de que 
ele reescreveria sua teologia sistemática a partir do diálogo das religiões. Infelizmente, não houve tempo suficiente. Tillich faleceu apenas cinco anos após sua visita ao Japão.

$\mathrm{O}$ artigo que aqui se inicia, pretende entender um pouco das questões levantadas por Paul Tillich sobre o budismo. Todavia, não nos prenderemos a esse âmbito. Tendo em vista o necessário horizonte dialogal, ousaremos colocar questões ao budismo amidista japonês que podem ser pensadas a partir do pensamento tillichiano. Essa necessidade se dá principalmente porque o contato direto que nos foi registrado é do diálogo de Paul Tillich com pensadores da Universidade de Otani, em Kyoto. Essa universidade pertence à JodoShinshu (Escola da verdadeira Terra Pura). Mas não houve um diálogo imediato com as outras escolas da Terra Pura e suas particularidades doutrinárias.

Alguns caminhos serão trilhados para o desenvolvimento da presente discussão. Primeiramente, há de se situar o budismo no Japão, bem como as escolas da Terra Pura. Em seguida, deve-se narrar um pouco sobre a viagem de Tillich ao Japão e sobre suas impressões. Só então, pode-se partir para a questão mais teológica/filosófica/budológica, discutindo os problemas ao redor do nome sagrado do Buda Amida e da esperança de salvação pela Terra Pura.

\section{O budismo amidista no Japão}

O Japão é conhecido pela presença do budismo de maneira substancial. Entretanto, nem sempre tem-se a noção correta de quantas formas diferentes de budismo existem em país geograficamente tão pequeno. Também nem sempre se entende corretamente a relação do budismo com o Estado japonês e com a cultura japonesa. Nessa primeira parte do texto, serão traçados alguns desses pontos para que se possa entender a particularidade do budismo amidista japonês.

O Japão não é originalmente budista, bem como o budismo não é originalmente japonês. O budismo surge no contexto do politeísmo indiano, e mesmo assim, não requer de maneira imediata o papel de religião organizada. O processo de construção estrutural e doutrinária do budismo como religião se dá ao longo de seu deslocamento no tempo e no espaço. O budismo caminha em direção ao oriente e encontra 
em seu caminho culturas diversas, com as quais dialoga e se molda ao mesmo tempo em que é moldado por elas.

Normalmente, conhece-se o budismo pelo mito da iluminação do príncipe Sidharta Gautama, na Índia. A história narra um homem que com inquietação de espírito, deixa os luxos de sua corte e experimenta as realidades da vida cotidiana em seus extremos. Após experimentar os excessos e os mínimos, ele afirma que o caminho correto é o caminho do meio.

No Japão, o budismo se torna uma religião popular a partir dos xogunatos de Kamakura. No entanto, o budismo já se fazia presente há alguns séculos no país, mas era majoritariamente reservado ao contexto monástico.

A partir do período dos xogunatos (governos militares) de Kamakura鎌倉 時代 (1185-1333) e do período Muromachi室町時代 (1336-1573),o Budismo começou a penetrar profundamente nas vidas das pessoas comuns. Sociologicamente dizendo, o movimento começou dos estratos mais altos da sociedade para baixo, ou do centro para a periferia. Isso se difere do Cristianismo primitivo, por exemplo, que primeiro se enraizou entre as pessoas mais humildes e depois atingiu as pessoas de classes mais altas. Nesse período, desenvolveram-se várias escolas budistas no Japão, que podem ser divididas em duas grandes linhas: as escolas amidistas que pregavam que qualquer pessoa poderia ir ao paraíso depois da morte, recitando ou invocando o nome de Buda, como a 浄土宗Jōdo-shū(Terra Pura), 浄土真宗JodoShinshū e日蓮宗Nichiren-shū; e uma outra linha, mais filosófica, conhecida como 禅宗 Zen-shū, que enfatizava a liberação através da meditação e que foi rapidamente adotada pelas classes superiores e teve um impacto profundo na cultura japonesa, como 臨済 宗Rinzai-shū e 曹洞宗Sōtō-shū (PEREIRA, 2006, p.12).

Até hoje, no Japão, encontra-se a divisão entre essas duas grandes linhas: uma linha amidista e outra mais filosófica. Como o próprio título do presente artigo apresenta, falaremos aqui sobre a relação de Paul Tillich com o budismo amidista.

No Japão, o budismo é caracterizado por suas adaptações. Por esse motivo, existe uma certa dificuldade de compreensão sobre a extensão da presença do budismo em tal país.

Os monges budistas japoneses normalmente não aderem ao código tradicional de conduta para a comunidade budista ou sangha (Vinaya). Somen- 
te para ilustrar: enquanto o código tradicional requer a abstenção sexual e o não-consumo de carne ou álcool, os monges japoneses geralmente incorporam carne e álcool às suas dietas e se casam após o término do treinamento monástico. $\mathrm{O}$ antecedente do casamento de monges foi criado por Shinran(1173-1262), o fundador do ramo JôdoShinshû (PEREIRA, 2006, p.7).

A questão das normas de conduta monásticas é um simples exemplo para que se entenda uma questão muito mais profunda, a saber, a capacidade de adequação e adaptação do povo japonês e a necessidade da manutenção de sua memória coletiva. Ao contrário do que se possa imaginar sobre a estruturação dos espaços religiosos em uma cultura e em um país, as religiões no Japão não excluíram umas as outras. Essas religiões foram se incorporando no cotidiano da comunidade até que estivessem enraizadas, gerando muita confusão sobre o que é que pertence originalmente a cada tradição.

O Budismo japonês tende a ser sincrético, na medida em que influencioue se apropriou de outras tradições religiosas (Xintoísmo, Confucionismo, Taoísmo e crenças populares), além de ter patrocinado e estimulado cultos extremamente sincréticos como é o caso dos já mencionados Ryôbu Shintô (Xintoísmo Dual) e Shugendô (ordem dos ascetas montanheses) (PEREIRA, 2006, p.6).

A presença do sincretismo na história do Japão é intensa e persiste até os dias atuais. Esse sincretismo pode ser tanto de origem religiosa quanto de cunho sociocultural. Muitas vezes, crenças são sobrepostas mesmo não parecendo que tal relação seja lógica. Também não há uma preocupação muito grande com a separação entre o que é doutrinariamente formulado e aquilo que se incorpora do cotidiano popular. É muito mais importante para o povo japonês que se pratique determinado ritual do que a justificação do mesmo pela via racional.

Isso se deve, de certo modo, a um conceito pouco conhecido no ocidente, mas essencial para a compreensão da mentalidade japonesa. No ocidente, temos a história da lógica derivada da filosofia grega, sendo que o organum aristotélico é a base de todo o desenvolvimento da história da filosofia lógica. Além disso, passamos pelo cogito cartesiano, pelo empirismo inglês e pelo tão bem quisto iluminismo. Em 
todo esse processo se preserva a linearidade da lógica. O oriente em geral e o Japão em particular, não possuem a base aristotélica nem a reforma cartesiana. O pensamento iluminista chega ao país de maneira tardia, quando a mentalidade japonesa já tinha se formado de uma maneira diferente.

O conceito em questão é o “Aimai”(あいまい). Aimai nada mais é do que a importância da ambiguidade. É a possibilidade de compreensão de que algo não está totalmente certo ou totalmente errado, incluindo a via que aceita que algo pode estar certo e errado ao mesmo tempo. Ou seja, há na cultura e na mentalidade japonesa algo bem distante da lógica formal ocidental (DAVIES, 2002, p.9).

$\mathrm{O}$ conceito de Aimai aplicado à religião permite que mitos e ritos se complementem ou se encaixem de uma maneira que não precisa ser necessariamente explicada. Isso é ilustrado muito bem pelas crendices populares do povo japonês. Um bom exemplo disso são os Omamori (御守 / お守り)amuletos de proteção de origem xintoísta, mas que são encontrados em quase todos os espaços religiosos japoneses.

Tendo como base esse breve contexto sobre o budismo japonês e sobre a forma de pensar a religião no Japão, passaremos agora a narrar o encontro de Paul Tillich com o budismo japonês.

\section{A visita de Paul Tillich ao Japão}

Em 1960 Paul Tillich viajou ao Japão, acompanhado de sua esposa, Hannah Tillich. Essa viagem foi importante para Tillich em diversos aspectos, sobretudo sobre a própria postura que o autor passa a tomar a partir de tal abertura cultural. O pensamento teológico de Tillich passa por uma mudança, na qual ele deixa de lidar com os aspectos mais exclusivos do cristianismo e se preocupa com as relações dadas na historia das religiões, seus mitos, e seus sentidos.

Não posso formular o que significou antes que todas essas impressões tenham se acalmado em mim. Provavelmente, os outros notarão essa influência do Japão até mais do que eu mesmo. Mas eu sei que algo aconteceu: nenhum provincialismo ocidental que eu conheça será tolerado por mim de agora em diante, tanto em meu pensamento quanto em minha obra (TILLICH, apud Fukai, 2013, p.2). 
Essa decisão de não mais tolerar o provincialismo ocidental demonstra que o autor adota um posicionamento de crítica ao seu próprio trabalho, entendendo que o mesmo precisa se livrar de determinados vícios. Antes da viagem de Paul Tillich ao Japão, já havia uma relação de discordância com grande parte da ortodoxia de Karl Barth. A partir dessa abertura para o diálogo inter-religioso, Tillich assume de maneira mais evidente sua crítica em relação ao posicionamento barthiano de aceitar apenas Jesus, o Cristo, como evento salvífico válido dentre todas as narrativas revelatórias de todas as religiões.

Faustino Teixeira aponta que:

Em sua última conferência, realizada em outubro de 1965 na Universidade de Chicago, Tillich indicava a necessidade de uma renovação de sua teologia sistemática, no sentido de uma nova "interpretação do estudo teológico sistemático e dos estudos histórico-religiosos". Tratava-se de acionar a reinterpretação da tradição teológica à luz das novas reflexões indicadas pela história das religiões (TEIXEIRA, 2006, p.31).

Essa necessidade de renovação de sua própria teologia é o que indica a necessidade da produção de diálogos como o que é proposto no presente trabalho.

O diálogo de Paul Tillich com monges e estudiosos japoneses da Escola JodoShinshu foi publicado na revista KyôkaKenkyû, em 1960. Os principais interlocutores de Tillich na Universidade de Otani, em Kyoto foram Atsushi Nobukuni e Rijian Yasuda (1900-1982), intermediados pelo tradutor Richard De Martino. De certo modo, sabemos que Tillich possuía um carinho especial pela Universidade de Otani, bem como pelo budismo amidista, pois havia recebido Kosho Otani (19112002) por um ano em sua casa em Nova Iorque, quando ele era ainda um jovem monge que havia saído do Japão para estudar na Universidade de Columbia, em nova Iorque. Kosho Otani viria a se tornar 23* patriarca da JōdoShinshu Otani-ha Higashi Honganji, braço importante do budismo amidista no Japão. Quando esteve em Kyoto, Tillich chegou a assistir a um ofício conduzido por Kosho Otani, conheceu seu templo e participou de discussões organizadas pelo monge (FUKAI, 2013, p.214). A mesma ordem de Otani é presente no Brasil nos dias 
de hoje. Ela veio para atender os imigrantes japoneses e hoje possui sua estrutura que conta com monges tanto japoneses quanto brasileiros.

Quando Tillich estava no Japão, ele teve duas preocupações básicas em seus diálogos. A primeira seria a compreensão da piedade popular dos japoneses. Em segundo lugar, ele tentava entender algo sobre a existência de uma reforma ou de um aspecto reformador na história do budismo japonês. Quando questionado sobre os motivos de sua insistência em tais temáticas, afirmou que:

Veja, uma discussão sobre ser e não ser também ocorreu nesta tarde e foi uma discussão filosófica usual - eu poderia tê-la feito tanto aqui quanto em Cambridge. $\mathrm{O}$ que eu quero entender aqui no Japão é o poder religioso que o Budismo factualmente tem ou não. Estou buscando isso o tempo todo (TILLICH apud Boss, 2009, p.262).

Antes de ir ao Japão, Paul Tillich já tinha algum contato com estudiosos do budismo japonês. Em 1951 ele conheceu Daisetz Suzuki, provavelmente a partir de uma mediação feita por Karen Horney (18851952). Em 1953, Tillich reencontrou Suzuki em Ascona, na Suíça. Em 1957 Tillich conheceu Shin'ichi Hisamatsu (1889-1980), pois ele foi professor visitante de Harvard por um semestre. Os dois pensadores citados eram mestres Zen budistas (BOSS, 2009, p.257).

Tillich foi convidado para ir ao Japão pelo "comitê de intercâmbio cultural", situado tanto em Nova Iorque quanto em Tóquio. O autor aproveitou para conhecer outras religiões além do budismo. O teólogo se encontrou com representantes do Xintoísmo, religião que ele afirmava não estar apto a compreender naquele momento, e com representantes de novas religiões como Tenrikyo e o RisshoKoseikai. Além disso, Tillich também reservou um tempo para dialogar com cristãos japoneses.

Como resultado de seus diversos diálogos e de sua agenda cheia de compromissos no Japão, Tillich acaba chegando a uma conclusão que toca em algo bastante particular para o budismo japonês, a questão da identidade:

As discussões com os budistas me mostraram que o principal ponto de diferença entre eles e o cristianismo - a valoração diferente sobre o individual, o sentido da história, as relações interpessoais, reforma social e religiosa, finitude e culpa - é o contraste entre o princípio da identidade e o princípio da participação (TILLICH apud Boss, 2009, p.259). 
Essa afirmação de Paul Tillich será bastante útil para que se entendam as questões que serão postas a seguir.

\section{A questão do Nome Sagrado (Myogo)}

No budismo da Terra Pura, o nome do Buda possui um papel central, que precisa ser entendido para que possamos continuar nossa discussão. Amida é o Buda que recebe a todos aqueles que chamam pelo seu nome em sua Terra Pura. Uma vez que alguém morre na presente vida, pode nascer na Terra Pura do Buda Amida. Por isso, a prática mais recorrente do budismo amidista é a recitação do nome do Buda. No Budismo Japonês da Terra Pura, essa prática se dá a partir de diversas formas de entonação e ritmos de repetição da frase NamuAmidaButsu (南無阿弥陀仏). O Namu Amida Butsu é corriqueiramente chamado de Nembutsu, que é a recitação do nome sagrado, o Myogo.

Essa recitação possui um aparato lógico válido. O BudaAmida é o Budaque atinge sua iluminação a partir de um voto. Na verdade, o bosatsu Dharmakara, antes de atingir sua iluminação e se tornar o BudaAmida, fez quarenta e oito votos, sendo que em algumas escolas da Terra Pura, o décimo oitavo voto é considerado central. Esse voto resume os demais, pois explica justamente como funciona o sistema soteriológico do budismo amidista. $\mathrm{O}$ décimo oitavo voto afirma que todo ser senciente que chamar pelo nome do Buda Amida, confiando, nascerá em sua Terra Pura, caso contrário ele mesmo não alcançará a perfeita iluminação. Nesse ponto, há uma questão a ser entendida. Ainda existem seres sencientes que estão vivos nessa terra chamando pelo Buda Amida, recitando seu nome. No entanto, Buda Amida já goza de sua iluminação da Terra Pura, o que significa que ele não recusou a ninguém que chamou pelo seu nome a recepção em sua terra, caso contrário ele quebraria seu próprio voto. Há de se lidar com o fato de existir uma supra-temporalidade. Buda Amida já é Buda, portanto, iluminado. Mas, ele prefere estar em sua Terra Pura, cumprindo sua missão de ajudar todos os seres sencientes a atingirem a mesma condição de iluminados do que gozar da total vacuidade de seu estado. Ao abrir mão de seu pleno gozo na total vacuidade, o Buda Amida pratica seu princípio de compaixão, ajudando a todos aqueles que confiarem em seus votos e chamarem pelo seu nome. 
O nascimento na Terra Pura do Buda Amida não pode ser confundido com a plena iluminação. Nascer na Terra Pura ainda é um estágio anterior ao da iluminação. Todavia, é um estágio muito importante, pois acredita-se que não é possível voltar atrás, ou seja, não há como criar na Terra Pura um Karma negativo que te faça renascer nesta terra. Uma vez que se nasce na Terra Pura de Buda Amida, ouve-se com cuidado os ensinamentos do Buda e consegue-se atingir juntamente com ele a iluminação.

Quando Paul Tillich está na Universidade de Otani, dialogando com estudiosos budistas, ele elabora uma questão que acaba sendo bastante pertinente para a discussão entre os próprios budólogos das escolas amidistas. Tillich pergunta sobre o sentido da recitação do nome do BudaAmida, questionando se ele funciona ou não como uma oração.

Posso entender como um judeu, um cristão ou um muçulmano ora, porque a oração sempre nos leva a "outro ego", um alguém, e então se faz uma relação ego-outro. Para que alguém ora no budismo? Entendo muito em que um budista pode meditar [...]mas, por outro lado, na doutrina oficial e no pano de fundo teológico do budismo o elemento pessoal é quase engolido pelo elemento suprapessoal - seja esse o princípio Buda ou o princípio Amida, mas não é uma figura que pode ser olhada como uma pessoa. Mesmo assim, há muita oração acontecendo. Como isso pode se unir aos princípios fundamentais do budismo? Ou, para formular a questão mais precisamente, "para quem um budista ora se ele ora ao invés de meditar? (TILLICH in BOSS, 2009, 262).

Ao efetuar tal questão, Paul Tillich causa uma pequena discordância entre os presentes, pois a primeira resposta é negada pelos demais presentes. Inicialmente é respondido que a recitação do Nembutsu não é uma oração. O autor discorda, de modo que outra resposta lhe é dada. Responde-se então que há sim uma intenção de atingir a um "outro" quando se recita o nome do Buda Amida. Entretanto, explica-se que esse outro não é totalmente separado do eu, pois a natureza búdica está presente em todas as coisas (BOSS, 2009, p.261). É uma questão bem mais ampla tentar entender como o outro ao qual se dirige não é um totalmente outro. De maneira fortemente resumida, isso deriva do fato de que a natureza búdica é presente em todos e em tudo e não apenas na figura do BudaAmida. Mais uma vez se põe em questão o 
problema já citado sobre a diferença entre comunhão e identidade. De fato, Tillich insistiu bastante nesse conceito, pois julgou estar nele a diferença central entre o pensamento budista e o cristão.

Nesse momento, é importante lembrar que Paul Tillich elabora uma teologia que aceita a ressignificação dos símbolos religiosos, pois entende que é importante que aquilo que é simbolizado prevaleça sobre o símbolo. Quando o autor propõe essa discussão sobre o Nome Sagrado, ele está justamente tentando entender esse sentido que está por trás do símbolo. Tillich diz que "a fé que, através do Nome, penetra até algo que está por trás do Nome, é diferente da fé que usa o Nome como um instrumento. Eu quero discutira questão do Nome até esse ponto" (TILLICH, 2002). De certa forma, o autor está preocupado com o fato do símbolo ter substituído aquilo que ele simboliza na dinâmica da religião. Isso se enquadraria no conceito tillichiano de idolatria. Quando Tillich pergunta repetidamente sobre a piedade popular no budismo japonês é provável que ele queira entender se o crente budista tem de fato a noção da carga metafórica do Nembutsu e de seu potencial de apontamento para algo que está para além de si. Caso não se tenha tal consciência, no pensamento de Tillich, o Nembutsu seria apenas a prática de uma fórmula mágica de salvação que não possuiria sentido religioso real.

O que não chega a ser dito nesse diálogo entre Paul Tillich e os intelectuais Shin budistas é que a origem da prática da recitação do nome do Buda Amida no Japão está diretamente relacionada à preocupação com a piedade popular. Hōnen Shonin (1133-1212), fundador da escola da Terra Pura, JodoShu, afirmou que "a exclusiva prática do Nembutsu, que salva cem de cada cem, não deve ser preterida a práticas que salvam apenas um em cada mil. Por isso, foque na prática do Nembutsu e se esqueça das demais práticas" (MACHIDA, 1999, p.3).Hōnen Shonin acreditava que os seres humanos comuns, que não levassem uma vida monástica não conseguiriam alcançar a salvação a partir da prática da meditação, como proposto no budismo Zen. Inclusive, o feito seria muito difícil até mesmo para os monges. Portanto, seria necessária uma prática que entregasse a possibilidade razoável de salvação. Foi assim que o patriarca Hōnen Shonin levou o amidismo da China para o Japão, e fundou na primavera de 1175 em Yoshimizu a JodoShu. 
Sobre o aspecto popular da prática do Nembutsu no Japão, Soho Machida faz uma comparação direta da escola da Terra Pura em sua origem com os movimentos latino-americanos de libertação. Ele cita Gustavo Gutiérrez e Leonardo Boff e afirma que:

Tirando a enorme diferença de tempo e espaço, a prática exclusiva do Nembutsu de Hōnen pode ser considerada uma "teologia da libertação" do Japão medieval, pois há a presença de dois vetores, um secular e um religioso, gerando assim um potencial libertador contra a natureza hierárquica do velho budismo (as tradicionais escolas de Nara e do Monte Hiei) e contra a orientação transcendental da antiga crença na Terra Pura.

Como Paul Tillich é anterior ao movimento latino-americano da libertação, obviamente tal comparação não seria possível. Entretanto, ela reflete a preocupação tillichiana de encontrar algo reformador no budismo amidista. Talvez ele estivesse procurando algo que se encaixasse com sua ideia de princípio protestante. Após a discussão que circunda a prática do Nembutsu, o autor acaba entendendo que o NamuAmidaButsu não é considerada uma fórmula mágica a partir da qual a salvação se dá instantaneamente. Tillich afirma que o Nembutsu "trata-se de um símbolo a simbolizar o que qualquer pessoa é capaz defazer, em qualquer tempo e qualquer lugar. É isso que é simbolizado. O Nembutsu não é o som, é o fato de ser possível a qualquer pessoa, em qualquer lugar" (TILLICH, 2002, p.4).

A recitação do nome do Buda Amida está ligada à postura do crente do budismo amidista e expressa sua esperança de uma mudança ontológica final.

A seguir, veremos como se dá a dinâmica da salvação no pensamento amidista e qual seria a reação do pensamento tillichiano a esse propósito.

\section{O Poder cristológico do BudaAmida}

Ao contrário do que possa parecer à primeira vista, falar sobre o poder cristológico do BudaAmida não se trata de interpretar o Buda a partir da perspectiva cristã. $\mathrm{O}$ que se põe em questão é a potencialidade salvífica apresentada pelo mito e pela doutrina do Buda Amida. 
Paul Tillich foi inovador no sentido de estender a ideia de Cristo para a interpretação do processo soteriológico de outras religiões. Por isso, entende-se que ele não é um teólogo exclusivista (salvação exclusiva para o cristão), nem um teólogo inclusivista (salvação para qualquer religião através de Cristo), mas seria um teólogo do pluralismo religioso, ou seja, um teólogo que aceita que a salvação pode ocorrer em qualquer religião. Como já vimos no decorrer do trabalho, sua abertura mais significativa para a questão do diálogo das religiões se deu no final de sua vida, especialmente depois de ter tido o contato direto com o budismo no Japão.

Faustino Teixeira, apresenta de maneira bastante assertiva o resumo do pensamento de Tillich nesse sentido:

Em linha de descontinuidade com a perspectiva ortodoxa de Karl Barth a respeito da relação do cristianismo com as outras religiões, Paul Tillich enfatiza a ideia de que "as experiências reveladoras são universalmente humanas". Não há como conceber para Tillich a ideia de uma humanidade "abandonada por Deus", de uma história carente da presença do Espírito. A seu ver, a história da humanidade, em todos os seus períodos e lugares, esteve abraçada pela "Presença Espiritual". Sempre disponível ao espírito humano, o Deus misericordioso "irrompe, com poder salvífico e transformador, em toda a história em experiências revelatórias". A história da revelação não é algo que ocorre paralelamente ou à parte da história concreta, mas está a ela intimamente ligada. É em toda a história que se cumpre a história da revelação. As religiões são igualmente marcadas por "poderes reveladores e salvíficos". E a revelação para Tillich tem um significado bem preciso, identificando-se com aquilo que diz respeito ao ser humano "de forma última", incondicionalmente. É uma realidade que toca a dimensão mais profunda de cada ser: sua dimensão ontológica. (TEIXEIRA, 2006, p.34)

As experiências revelatórias são universalmente humanas. Talvez, essa seja a chave para compreender o princípio da relação entre as religiões no pensamento de Tillich. Entretanto, é necessário que se chame a atenção para alguns conceitos que estão ao redor do tema soteriológico para que se entenda a ideia mais ampla de seu sistema. Destacamos aqui os seguintes pontos:

- A relação entre religião e cultura;

- A ideia de Deus para além de Deus; 
Esses dois pontos servem como suporte para o entendimento da universalidade humana das experiências revelatórias. Primeiramente, uma das ideias mais extensas do pensamento de Tillich é a ideia da relação necessária entre religião e cultura. Um elemento não pode ser compreendido sem o outro, pois a religião está no fundamento da cultura, assim como a cultura está na forma da religião. Isso significa dizer, mesmo que de forma bastante coesa para atingir o presente intento, que a cultura é aquilo que o ser humano produz como forma de sua expressão no mundo, e que na base de tudo aquilo que ele expressa está o problema ontológico fundamental, o sentido da existência. Portanto, toda vez que o ser humano se expressa, ele expressa em maior ou menor grau seu problema ontológico fundamental, sua pergunta pelo âmbito incondicionado necessário para a manutenção de sua situação condicionada pelo destino, insignificação e morte. Consequentemente, a questão ontológica fundamental, que é a pergunta religiosa propriamente dita, não pode ser expressa de outro modo senão nas linguagens da cultura. O formato em que cada ser humano expressa sua preocupação religiosa depende do contexto de sua linguagem cultural. Esse ponto traz um pressuposto importantíssimo para que se entenda que as religiões não possuem diferenças pela própria questão religiosa. $\mathrm{O}$ ser humano, dentro de sua condicionalidade e alienação existencial, busca sempre o mesmo sentido ontológico fundamental, mas o faz dentro das particularidades de sua cultura, ou seja, dentro daquela linguagem em que ele pode melhor se expressar.

O segundo conceito que escolho destacar é que Paul Tillich se utiliza da ideia de God beyond God, que pode ser traduzido ao português obedecendo ao seu sentido teológico e filosófico como "Deus para além de Deus". Se tomarmos como exemplo a perspicácia da criança que pergunta a sua mãe "se Deus criou tudo, quem criou Deus?", entenderemos que o que a criança está fazendo é expressar a necessidade de entender a origem que está por traz da narrativa mítica. Nesse sentido, essa questão deixa de ser infantil e acaba sendo de fato uma das preocupações centrais do âmbito religioso. Em geral, toda a teologia tende a responder às questões do mito dentro da própria narrativa mítica, jogando as lacunas para um porão metafísico no qual não se deve mexer. O que Tillich propõe com seu conceito de Deus para além de 
Deus não é narrar algum outro mito que dê sustento ao primeiro mito. Ele está apenas utilizando a linguagem religiosa "Deus" para dizer que o Deus presente no mito é uma representação linguística metafórica que aponta para o incondicionado de fato que não está contido no mito, mas que é a fonte ontológica básica da existência e de sua manutenção. Assim, a metáfora que está contida no mito participa de sua revelação, mas não é o próprio elemento a ser revelado, de modo que, a devoção última a essa metáfora é o que o próprio autor considera como sendo uma idolatria. A metáfora mítica serve para apontar para o incondicionado, esse sim sendo o ponto ao qual o ser humano deve se ligar no seu processo de religião.

Tendo como base os pontos destacados, podemos dar um passo adiante. Quando Tillich estava dialogando com estudiosos budistas da JodoShinshu em Kyoto no ano de 1960, ele chega à seguinte conclusão:

Seu mito e sua doutrina nos dão a imagem poderosa de uma pessoa que, renunciando ao Nirvana, estabelece um juramento. Se tivermos essa imagem poderosa como pano de fundo, se nela estiverem implícitos todos os ensinamentos e todos os atos dessa pessoa, eu poderia imediatamente compreender que esse Nome do BudaAmida contém um conteúdo semântico suficientemente forte para despertar em alguém a sensação de ter sido salvo e para se constituir num poder salvífico. Se não tivermos um sistema simbólico, o Nembutsu será, então, uma simples magia (TILLICH, 2002).

Essa afirmação de Tillich é um exemplo de seu pluralismo religioso. Ele está afirmando que o nome do Buda Amida possui um poder salvífico, desde que o mesmo seja compreendido dentro de seu sistema simbólico.

A introdução da perspectiva amidista no Japão do século XII indica uma alternativa de salvação diferente daquelas até então adotadas. $\mathrm{O}$ mesmo princípio adotado por Hōnen é o princípio que acaba norteando a obra de Shinran Shonin, patriarca da escola JodoShinshu.

Nesse sentido, sou como Shinran, que em seu desespero concluiu que elenão tinha escolha a não ser seguir o caminho da Terra Pura proposto porseu mestre Hōnen. Eu também fiz a meditação de auto empoderamento,mesmo não sendo pelos vinte anos que Shinran tentou, e estou cientede minhas limitações a esse respeito: não me salvarei por conta próprianessa vida por minhas meditações (BECKER, 2008, p. 79). 
Shinran, que fora discípulo de Hōnen, acaba aceitando a proposta diferente da tradicional que lhe é ensinada porque ele já havia meditado por vinte anos e acabara concluindo que não conseguiria atingir a salvação por conta própria.

Pelo fato dos votos do bosatsu Dharmakara indicarem que todos aqueles que recitarem seu nome serão recebidos em sua Terra Pura e que ninguém há de retroceder karmicamente desde lá, pode-se criar a errada impressão de que a salvação no budismo amidista japonês é um ato automático.

A salvação não é incondicional, ela depende de nosso próprio movimentoem sua direção. É como se fosse a pipa de Ben Franklin. Há uma energiatremenda lá em cima no ar, mas não podemos nunca dominar essa energiase não fizermos o perigoso esforço de levantar nossa pipa na chuva deraios. Então, pelo fato de conseguirmos fazer isso, a energia é canalizadapor nossos esforços débeis e podemos guardar tal energia num recipiente(BECKER, 2008, p. 79).

É necessário que o crente tenha uma atitude para sua própria salvação. É necessário que confie na compaixão do Buda Amida e chame pelo seu nome. A salvação não é propriamente nascer na Terra Pura de Buda Amida. Não se deve confundir a Terra Pura com algum céu que seja o repouso eterno. A Terra Pura é o local onde pode-se atingir a iluminação, romper o ciclo de Samsara e entrar no Nirvana.

Soho Machida propõe que o termo "Ojo" (salvação) utilizado por Hōnen Shonin seja entendido a partir de um sentido duplo.

Uma leitura alternativa é notar que Hōnen usa a palavra Ojo (salvação) em dois sentidos. Por um lado, Ojo é o fim da vida no qual as chamas da paixão são extintas, e por outro lado, Ojo é a convicção, enquanto alguém ainda está vivo, que a morte trará tal repouso absoluto (MACHIDA, 1999, p.93).

Com essa dupla compreensão da utilização do termo Ojo por Honen Shonin, pode-se ter a ideia de como a doutrina da Terra Pura funciona dentro do âmbito mais geral do budismo. Por um lado, Ojo significa a extinção das paixões que se dá a partir da morte. Nesse sentido, entende-se que após a morte há o nascimento na Terra Pura, onde não existem paixões. Por outro, Ojo é a fé sobre sua própria salvação 
pela compaixão do Buda Amida. Respeitando todas as diversidades que existem entre as religiões, Ojo em seu segundo sentido, lembra parcialmente o conceito cristão de graça. A limitação dessa comparação reside também no já citado problema da diferença entre identidade e comunhão. Enquanto o cristianismo lido por Tillich propõe a comunhão de dois sujeitos totalmente separados, o budismo não aceita a separação total desse sujeito, impossibilitando assim que alguém possa liberar graça para outro alguém. Existe uma subjetividade parcial no budismo. Ela é justamente uma das paixões que precisam ser cessadas para que se possa atingir a salvação.

Nishida acreditava que o ser humano (aquele que entoa o Nembut$s u$ neste mundo) e o absoluto (Amida no outro mundo) poderiam se encontrar apenas a partir da morte do self. Por morte ele não queria dizer apenas morte física, mas a negação absoluta da subjetividade (MACHIDA, 1999, p. 101).

A negação absoluta da subjetividade não depende necessariamente da morte física. A crença na salvação pela Terra Pura do Buda Amida faz com que o indivíduo entenda a necessidade da negação de sua subjetividade e da sua própria razão. Nada do que se tem como certo e como objetivo na vida faz diferença a partir do momento em que se confia plenamente na salvação pelo Buda Amida. Para ganhar "vida absoluta", ou na frase de Hōnen shoji o hanareru: "esta consciência no pensamento de Hōnen seria o retorno à ignorância, sem o qual o contato com a misericórdia incorporada ao nome do Buda Amida não poderia ser feito" (MACHIDA, 1999, p.102).

É necessário retornar à ignorância. Aceitar a alienação que existe em si e superá-la pela via do esvaziamento. Isso significa que, em termos tillichianos seria necessário repensar alguns de seus conceitos fundamentais.

Tillich afirmou, como vimos acima, que o Nembutsu possui conteúdo salvífico suficiente. Esse conteúdo se dá justamente porque há um "deus acima de deus" que garante sua existência. Isto é, quando se recita o nome do Buda Amida é que a fé na misericórdia e na compaixão de Buda Amida é praticada. Portanto, deveríamos relacionar tal ato com a coragem de ser: 
A fonte básica da coragem de ser é o "Deus acima de Deus"; este é o resultado de nosso empenho em transcender o teísmo. Somente transcendendo o teísmo pode a ansiedade da dúvida e insignificação ser incorporada à coragem de ser. O Deus acima de Deus é o objeto de todo anelo místico, porém o misticismo também deve ser transcendido a fim de alcançá-lo (TILLICH, 2001, p.143-144).

O problema que se nos apresenta agora não foi discutido por Tillich segundo os registros sobre sua viagem ao Japão. Como pensar que o anelo místico da prática do Nembutsu pode gerar a coragem de ser se a conditio sine qua non para a salvação pela Terra Pura de Buda Amida depende do esvaziamento da própria subjetividade. Julia Ching aponta que:

No que tange ao self, a doutrina budista é formulada em termos negativos. Ouvimos a doutrina do não-self (Pali: Anatta, ou sânscrito: Anatman). Essa doutrina é fruto do esforço de analisar a existência individual - não apenas humana, mas todos os dharmas ou elementos da existência - a partir de seu vazio(sunyata). De acordo com essa teoria todas as coisas e eventos (dharmas) devem ser "vazios" ou "esvaziados" de realidade, e o reconhecimento de sua vacuidade pode trazer o entendimento real (CHING, 1984, p.2).

Quando Tillich propõe sua coragem de ser, ele faz questão de apresentar a diferença entre coragem de ser como si próprio, coragem de ser como parte e a importância do não ser. Entretanto, a salvação pregada no budismo é a vacuidade, a ausência de qualquer ente ao qual se possa segurar. Portanto, é bem difícil imaginar como seria possível a coragem de ser como algo derivado do Ser-em-si. Na verdade, o budismo trilharia o caminho oposto, pois a liberdade de não ser (iluminação) é o que indica a possibilidade do crente buscar a coragem de não ser como si próprio. A ansiedade do destino e da insignificação não teria o mesmo sentido se a proposição última não residisse na auto-afirmação do sujeito.

Talvez, no âmbito da correlação, seria necessário desenvolver uma categoria de coragem de ser como vacuidade. A coragem seria nesse caso o ato de procurar o não ser a despeito do ser. Na verdade, seria possível utilizar a terminologia dupla. Tanto falar da coragem de modo positivo quanto de modo negativo. A transcendência continuaria 
apontando para o não ser, para o vácuo (nirvana) que há além do primeiro "deus" (Buda Amida).

Segundo Paul Tillich, o que expressa essa superação da religião pela Presença Espiritual é o "princípio protestante", uma categoria chave em sua abordagem teológica, e que vem articulada com a "substância católica". Enquanto o "princípio protestante" é uma barreira protetora contra as forças de "profanização e demonização" das igrejas e religiões, não se atendo às igrejas da Reforma; a "substância católica" traduz a "corporificação concreta da Presença Espiritual". O aprofundamento da compreensão destas duas categorias centrais no pensamento de Tillich e o exercício de sua extensão às outras religiões tornam-se chave essencial para o diálogo inter-religioso, além de indicar que este encontro vem animado por uma indispensável dimensão experiencial e mística (TEIXEIRA, 2006, p.39).

Mesmo com a possível necessidade de se pensar a tradução da coragem de ser tillichiana para os termos budistas, o elemento sagrado que ele afirma existir no budismo amidista japonês indica a existência do seu princípio protestante em tal religião. Como vimos, a origem do budismo amidista e da prática do Nembutsu no Japão tem um contexto de reviravolta social que indica a luta contra uma demonização da estrutura budista tradicional.

\section{Considerações finais}

Pode-se dizer que Paul Tillich parece ter encontrado o problema central para a construção do diálogo inter-religioso entre cristianismo e budismo: a questão da comunhão e da identidade. A comunhão continua a ser a categoria que reflete os anseios cristãos enquanto que a identidade é a única relação possível de acordo com o princípio budista. Mesmo assim, não se deve esquecer dos problemas menores que estão ao redor desse primeiro problema e que podem acabar sendo o motivo de incompreensão entre as religiões. O conceito de Aimai que foi apresentado no texto é um exemplo de como a própria lógica oriental funciona de maneira diferente da lógica cristã ocidental. Há de se respeitar essa diferença e não forçar para que as categorias japonesas se encaixem nas metáforas ocidentais. 
Não se deve confundir a Terra Pura do Buda Amida com a ideia cristã de céu. Apesar da Terra Pura ser narrada como um paraíso, uma terra de bem-aventuranças, deve-se entender que garante a salvação, mas não é ainda a salvação propriamente dita. De semelhante modo, não se deve confundir o Buda Amida com a ideia cristã de Deus. Pode-se sim utilizar as categorias de transcendência do deus para além de deus para entender como o nome do Buda simboliza algo para além do mesmo. Também não se pode confundir a compaixão do Buda Amida com a ideia cristã de graça, mesmo podendo dizer em termos tillichianos que há em Buda Amida um poder cristológico.

Respeitados esses pontos, partimos agora para alguns apontamentos mais particulares. Primeiramente, há de se entender que além do potencial salvífico do Buda Amida, o budismo da Terra Pura possui um caráter que se enquadra muito bem no conceito de princípio protestante. Hoje, teóricos de diversas escolas do budismo da Terra Pura no Japão reclamam para si a semelhança com o movimento latino-americano de libertação, sendo que esse foi certamente o maior evento carregado de princípio protestante da história do cristianismo nas Américas. Portanto, há de se entender o princípio protestante que existe na história e na doutrina do budismo amidista japonês.

Em seguida, partindo para o lado que mais evidentemente se enquadra no âmbito da filosofia da religião, seria necessário questionar a relação entre ser e não ser no budismo amidista japonês para que a partir daí fosse possível a correlação dos elementos da coragem de ser. Esse ponto é importante pelo fato de que já defendemos no presente artigo que é possível entender no budismo amidista um deus para além de deus. A coragem de ser é a derivação necessária da ideia da transcendência do teísmo, o que implica aceitar que é necessário explicar a coragem de ser no budismo, respeitando o fato de que a salvação em tal religião é a vacuidade.

Quando os portos do Japão foram abertos aos comerciantes ocidentais, o cristianismo entrou no mesmo pacote. Muitos japoneses reconheceram no poder cristológico de Jesus algo muito igual à compaixão do Buda Amida. Assim, eles deixavam suas próprias tradições religiosas para praticar uma religião em que a salvação possuía uma vantagem: a substituição. Enquanto o Buda Amida é alguém que te 
ajuda (compaixão), Jesus é aquele que morre em seu lugar (amor). Mal sabiam eles que não estavam dotados dos pressupostos culturais que sustentam a religião. Paul Tillich entendeu essa dificuldade: comunhão versus identidade.

\section{Referências}

BECKER, C. Embracing the Pure Land vision: coming to Grips with Dying through Living. In: WATTS J.; TOMATSU, Y. Never die alone: Death as a birth I Pure land Buddhism. Tokyo: Jodo Shu Press, 2008.

BOSS, M. Tillich in dialogue with Japanese Buddhism: a paradigmatic illustration of his approach to inter-religious conversation. In: RE MANNING, Russel (org.).The Cambridge Companion to Paul Tillich. Cambridge: The University Press, 2008.

CHING, J. Paradigms of the Self in Buddhism and Christianity. BuddhistChristian Studies. Vol. 4 (1984), pp. 31-50. Published by: University of Hawai'i Press. Hawai, 1984.

DAVIES, R. The japanese mind: understanding contemporary japanese culture. Tokyo/Vermonte: Tuttle, 2002.

DESSI, U.The Pure Land as a Principle of Social Criticism. Japanese Religions, Vol. 32 ( 1 \& 2): 75-90. Kyoto, 2008.

FUKAI, T (ed.). Paul Tillich - Journey to Japan in 1960. New York: De Gruyter, 2013.

MACHIDA, S. Renegade Monk: Hōnen and Japanese Pure Land Buddhism. Berkeley and Los Angeles: University of California Press, 1999.

ROGERS, C; TILLICH, P. Carl Rogers Dialogues. Diálogo entre Carl Rogers e Paul Tillich (1965). Tradução: Marcos Ricardo Janzen. Revisão Técnica: Gustavo Vieira da Silva e Adriano Holanda. Rev. Abordagem gestalt. v.14 n.1 Goiânia jun. 2008.

TEIXEIRA, F. A substância católica e as religiões. Revista Eletrônica Correlatio n. 10. São Bernardo do Campo. Novembro de 2006.

TILLICH, P. A coragem de ser. 6 ed. São Paulo: Paz e Terra, 2001.

Do nome Sagrado. Tradução de Ricardo Gonçalves. In: Revista Correlatio. V.1, N.2. São Bernardo do Campo: Metodista, 2002. 